\title{
Suppression of HIV-1 Tat-induced monocyte adhesiveness by a cell-permeable superoxide dismutase in astrocytes
}

\author{
Ha Yong Song', Sung Mi Ju', Ji Ae Lee', \\ Hyung-Joo Kwon ${ }^{2}$, Won Sik Eum ${ }^{1}$, Sang Ho Jang ${ }^{1}$, \\ Soo Young Choi ${ }^{1,3}$ and Jinseu Park ${ }^{1,3,4}$ \\ ${ }^{1}$ Department of Biomedical Science \\ ${ }^{2}$ Department of Microbiology, College of Medicine \\ ${ }^{3}$ Research Institute for Bioscience and Biotechnology \\ College of Natural Sciences \\ Hallym University \\ Chuncheon 200-702, Korea \\ ${ }^{4}$ Corresponding author: Tel, 82-33-248-2116; \\ Fax, 82-33-256-3420; E-mail, jinpark@ hallym.ac.kr
}

Accepted 1 November 2007

Abbreviations: ADC, AIDS dementia complex; ICAM-1, intercellular adhesion molecule-1; Tat, transactivator of transcription; ROS, reactive oxygen species; VCAM-1, vascular cell adhesion molecule-1

\begin{abstract}
HIV-1 Tat is considered to be one of key players to facilitate monocyte entry into the CNS, which is characteristic feature of AIDS-related encephalitis and dementia. This study was performed to determine the regulatory function of superoxide dismutase (SOD) on the HIV-1 Tat-induced signaling pathways leading to NF- $\kappa B$ activation, expression of adhesion molecules, and monocyte adhesion in CRT-MG human astroglioma cells by using cell-permeable SOD. When cell-permeable SOD was added to the culture medium of CRT-MG cells, it rapidly entered the cells in dose- and time-dependent manners. Treatment of astrocytes with cell-permeable SOD led to decrease in Tat-induced ROS generation as well as NF- $\mathrm{KB}$ activation. Cell-permeable SOD inhibited the activation of MAP kinases including ERK, JNK and p38 by HIV-1 Tat. Treatment of CRT-MG cells with cell-permeable SOD significantly inhibited protein and mRNA levels of ICAM-1 and VCAM-1 up-regulated by HIV-1 Tat, as measured by Western blot analysis and RT-PCR. Furthermore, enhanced adhesiveness of monocyte to astrocyte by HIV-1 Tat was significantly abrogated by pretreatment with cell-permeable SOD fusion proteins. These data indicate that SOD has a regulatory function for HIV-1 Tat-induced NF- $\mathrm{KB}$ activation in as-
\end{abstract}

trocytes and suggest that cell-permeable SOD can be used as a feasible therapeutic agent for regulation of ROS-related neurological diseases.

Keywords: cell adhesion; gene products, tat; HIV; inflammation; intercellular adhesion molecule-1; NF$\kappa B$; reactive oxygen species; superoxide dismutase; vascular cell adhesion molecule-1

\section{Introduction}

AIDS dementia complex (ADC) is a neurological disorder associated with HIV infection and affects up to $50 \%$ of adult AIDS patients. One of the characteristic features of ADC is the infiltration of monocytes into the CNS which represents one of the early steps to inflammatory events within the CNS (Ozdener, 2005; Rumbaugh and Nath, 2006). Considerable evidences suggest that abnormal expression of cell adhesion molecules and cytokine dysregulation mediate entry of monocytes into the CNS (Weiss et al., 1999; Pu et al., 2003; D'Aversa et al., 2004).

HIV-1 Tat (transactivator of transcription) protein, which can be secreted from the infected cells, has the ability to enter uninfected cells and exert its activity on the expression of various adhesion molecules including vascular cell adhesion molecule-1 (VCAM-1) and intercellular adhesion molecule-1 (ICAM-1) in human endothelial cells and astrocytes (Dhawan et al., 1997; Woodman et al., 1999; Song et al., 2007). Up-regulation of expression of adhesion molecules such as ICAM- 1 and VCAM-1 by HIV-1 Tat may induce a series of interactions between monocytes, endothelial cells, and astrocytes, facilitating infiltration of monocytes into the CNS (Rappaport et al., 1999; Langford and Masliah, 2001). Therefore, HIV-1 Tat may be an important regulator in the trafficking of monocytes into the CNS which may contribute to the development of HIV-associated pathologies including ADC (Rappaport et al., 1999).

Stimulation of astrocytes with HIV-1 Tat resulted in activation of NF- $\kappa B$ which was responsible for up-regulation of various cytokines, chemokines and adhesion molecules (Nicolini et al., 2001; Song et al., 2007). Although the mechanisms of Tat-mediated NF- $\mathrm{KB}$ activation remain to be elucidated, several studies have implicated the in- 
volvement of Tat-induced oxidative stress (BruceKeller et al., 2001; Song et al., 2007). HIV-1 Tat can increase levels of reactive oxygen species (ROS) directly and indirectly which in turn activates $\mathrm{NF}-\kappa \mathrm{B}$, a redox-sensitive transcriptional factor. ROS such as superoxide anion $\left(\mathrm{O}_{2}{ }^{-}\right)$and hydrogen peroxide $\left(\mathrm{H}_{2} \mathrm{O}_{2}\right)$ can act as second messengers in the intracellular signaling pathways involved in expression of many proinflammatory genes (SchulzeOsthoff et al., 1997; Brenneisen et al., 2002).

In the previous study, we showed that ROS generated by HIV-1 Tat mediates NF-kB activation, up-regulation of ICAM-1 and VCAM-1 and subsequent increased monocyte adhesion to astrocytes by using various antioxidants (Song et al., 2007). These results suggest that prevention of ROS generation upon Tat stimulation is one of strategies to control Tat-induced monocyte infiltration into the CNS. Although previous studies have demonstrated that several antioxidants can inhibit NF-KB activation by HIV-1 Tat, suggesting the involvement of ROS, the molecular mechanisms by which HIV-1 Tat mediates NF- $\kappa \mathrm{B}$ activation are poorly understood. Due to broad effects of antioxidants on cellular physiology, it would be difficult to study the exact role of ROS in HIV-1 Tat induced NF- $\kappa B$ activation. Therefore, in this study, we explored the role of ROS generation in HIV-1 Tat-induced NF$\kappa \mathrm{B}$ activation and resulting enhanced adhesiveness of monocyte to astrocyte by using cell-permeable PEP-1-SOD. PEP-1-SOD has been shown to exert a protective effect against oxidative stress in various cell types and in vivo disease models (Eum et al., 2004; Choi et al., 2006). We report herein that SOD has a regulatory function for HIV-1 Tat-induced NF- $\mathrm{B}$ activation, up-regulation of ICAM-1/VCAM-1 and increased monocyte adhesion to astrocytes.

\section{Materials and Methods}

\section{Cell culture}

CRT-MG human astroglial cells and THP-1 human monocytic cells were maintained in RPMI 1640 medium supplemented with $10 \%(\mathrm{v} / \mathrm{v})$ heat-inactivated $\mathrm{FBS}$, penicillin $\mathrm{G}(100 \mathrm{U} / \mathrm{ml})$, streptomycin $(100 \mu \mathrm{g} / \mathrm{ml})$ and L-glutamine $(2 \mathrm{mM})$ at $37^{\circ} \mathrm{C}$ in a humidified atmosphere containing $5 \% \quad \mathrm{CO}_{2}$ and 95\% air (Choi et al., 2002; Park et al., 2003).

\section{Reagents}

Calcein acetoxymethyl ester (calcein-AM) was purchased from Molecular Probe (Eugene, OR). Primary antibodies against ICAM-1, VCAM-1, actin and p65 (Santa Cruz, CA), and phosphor-p38, phosphor-ERK, or phosphor-JNK, total-p38 MAPK, total-ERK, and total-JNK (Cell Signaling Technology, Beverly, MA) were obtained commercially. HRP-conjugated anti-rabbit or goat antibodies were supplied by Sigma (St. Louis, MO).

\section{Purification of recombinant HIV-1 Tat protein}

Recombinant HIV-1 Tat protein was purified under native conditions as described previously (Song et al., 2007). Endotoxin levels for the Tat preparation were below the detection limit $(<0.1 \mathrm{EU} / \mathrm{ml})$ as tested by Limulus Amoebocyte Lysate assay (BioWhitaker, Walkersville, MD). The integrity and purity of the HIV-1 Tat proteins were assessed by SDS-PAGE followed by Coomassie blue staining. The biological activity of Tat was confirmed by a transactivation assay in HeLa cells transfected with a plasmid containing an HIV LTR-luciferase gene.

\section{Expression and purification of PEP-1-SOD fusion proteins}

PEP-1-SOD expression vector was constructed to express the PEP-1 peptides (KETWWETWWTEWSQPKKKRKV) as a fusion with human $\mathrm{Cu}, \mathrm{Zn}$ SOD. Expression and purification of SOD fusion proteins were carried out as described previously (Eum et al., 2004; Choi et al., 2006). SOD fusion proteins were expressed by inducing $E$. coli BL21 cells transformed with plasmids encoding the SOD or PEP-1-SOD fusion proteins with IPTG. To prepare SOD fusion proteins, the induced cells were pelleted and lysed in a binding buffer $(5 \mathrm{mM}$ imidazole, $500 \mathrm{mM} \mathrm{NaCl}, 20 \mathrm{mM}$ Tris- $\mathrm{HCl}, \mathrm{pH}$ 7.9). The fusion proteins were purified by affinity chromatography on a $\mathrm{Ni}^{2+}$-IDA column, followed by desalting with a PD10 column (Amersham). The purified SOD fusion proteins dissolved in PBS containing $20 \%$ glycerol were then aliquoted and stored at $-80^{\circ} \mathrm{C}$.

\section{Western blot analysis}

Cell lysates were prepared by incubating cells in lysis buffer (125 mM Tris- $\mathrm{HCl} \mathrm{pH} 6.8,2 \%$ SDS, $10 \% \mathrm{v} / \mathrm{v}$ glycerol) at $4{ }^{\circ} \mathrm{C}$ for $30 \mathrm{~min}$. Samples of fifty $\mu \mathrm{g}$ protein were separated on a $10 \%$ SDSpolyacrylamide gel and the proteins electrotransferred to a nitrocellulose membrane, which was blocked with $10 \%$ dry milk in PBS. The membrane was probed with the indicated antibodies, and the immunoreactive bands were visualized by enhanced chemiluminescence (ECL; Amersham) as recommended by the manufacturer. 


\section{RT-PCR analysis}

Total RNA was isolated from CRT-MG cells using a Trizol reagent kit (Invitrogen, Gaithersburg, MD) according to the manufacturer's instructions (Zhang et al., 2005). The RNA $(2 \mu \mathrm{g})$ was reversibly transcribed with $10,000 \mathrm{U}$ of reverse transcriptase and $0.5 \mu \mathrm{g} / \mu \mathrm{l}$ oligo-(dT) ${ }_{15}$ primer (Promega, Madison, WI). PCR amplification of CDNA aliquots was performed with the following sense and antisense primers $\left(5^{\prime} \rightarrow 3^{\prime}\right)$ : VCAM- 1 sense, ATGCCTGGGAAGATGGTCGTGA; VCAM-1 antisense, TGGAGCTGGTAGACCCTCGTG; ICAM-1 sense, GGTGACGCTGAATGGGGTTCC; ICAM-1 antisense, GTCCTCATGGTGGGGCTATGACTC; beta-actin sense, GCGGGAAATCGTGCGTGACATT; and betaactin antisense, GATGGAGTTGAAGGTAGTTTCGTG. PCR was performed in $50 \mu \mathrm{l}$ of $10 \mathrm{mM}$ Tris- $\mathrm{HCl}$ (pH 8.3), $25 \mathrm{mM} \mathrm{MgCl}, 10 \mathrm{mM}$ dNTP, $100 \mathrm{U}$ of Taq DNA polymerase, and $0.1 \mu \mathrm{M}$ of each primer and was terminated by heating at $70^{\circ} \mathrm{C}$ for $15 \mathrm{~min}$. PCR products were resolved on a $1 \%$ agarose gel and visualized with UV light after ethidium bromide.

\section{Measurement of intracellular ROS}

Intracellular ROS were measured using 2',7'dichlorofluorescein diacetate (DCF-DA), which is converted by ROS into fluorescent 2',7'-dichlorofluorescein (DCF). CRT-MG cells $\left(1 \times 10^{5}\right.$ cells $)$ were incubated in the absence or presence of PEP-1-SOD or SOD fusion proteins for $1 \mathrm{~h}$, and then treated with HIV-1 Tat protein $(500 \mathrm{ng} / \mathrm{ml})$ for $15 \mathrm{~min}$. Cells were washed twice with PBS and incubated with DCF-DA $(10 \mu \mathrm{M})$ for $30 \mathrm{~min}$. The cellular fluorescent images were obtained using a Zeiss Axiovert S100 microscope with a confocal laser-scanning system (Bio-Rad MRC-1024ES) as previously described (Park et al., 2004). In a different set of experiments, intracellular superoxide generation was measured by using the conversion of nitroblue tetrazolium (NBT) to formazan according to a modified version of previously described method (Rook et al., 1985). NBT can be reduced by superoxide anion via one-electron transfer reactions (Tarpey and Fridovich, 2001). CRT-MG cells were incubated in the absence or presence of SOD fusion proteins for $1 \mathrm{~h}$, and then treated with HIV-1 Tat protein $(500 \mathrm{ng} / \mathrm{ml})$ for 15 min. Cells were washed twice with PBS and incubated with NBT $(1 \mathrm{mg} / \mathrm{ml})$ for $30 \mathrm{~min}$. CRT-MG cells were lysed and formazan was dissolved with $2 \mathrm{M} \mathrm{KOH}$ and 1.4 volume of DMSO. The absorbance was read at $654 \mathrm{~nm}$ with a microplate reader.

\section{NF- $\mathrm{KB}$ protein localization}

The NF- $\kappa B$ p65 nuclear localization was detected by indirect immunofluorescence assay using confocal microscopy as described previously (Kim et al., 2003). Briefly, CRT-MG cells grown on a glass slide in a 12-well plate were treated with HIV-1 Tat for $1 \mathrm{~h}$. After being washed in PBS, the cells were fixed with $4 \%$ ice-cold formaldehyde for $30 \mathrm{~min}$ and permeablized with $0.2 \%$ Triton X-100. Rabbit polyclonal antibody to human NF-kB p65 (1:500) was applied for $1 \mathrm{~h}$ followed by incubation with fluorescein isothiocyanate-conjugated goat anti-rabbit $\lg$ (1:500) for $1 \mathrm{~h}$. The cells were transferred to a chamber on the stage of a Zeiss Axiovert S100 microscope and observed with a confocal laser-scanning system (Bio-Rad MRC1024ES). The fluorescence images (excitation 494 $\mathrm{nm} / \mathrm{emission} 518 \mathrm{~nm}$ ) of the cells were recorded every $0.25 \mathrm{~s}(\times 640)$. To determine NF-kB localization by Western blot analysis, nuclear protein extracts were prepared as described previously (Park et al., 2003, 2004) and analyzed with using anti-human NF-אB primary antibody $(1: 1,000)$.

\section{Electrophoretic mobility shift assay (EMSA)}

CRT-MG cells were treated with HIV-1 Tat $(500$ $\mathrm{ng} / \mathrm{ml}$ ) for $1 \mathrm{~h}$, then nuclear extracts of CRT-MG cells were prepared and analyzed for NF- $\kappa B$ binding activity by EMSA as described previously (Park et al., 2003, 2004). An NF-kB consensus oligonucleotide (Promega) was used in the EMSA. The complementary oligonucleotide was annealed and end-labeled with $\left[\gamma^{32}{ }^{32}\right.$ P]ATP using T4 polynucleotide kinase. EMSA was performed in a total volume of $20 \mu \mathrm{l}$ at $4^{\circ} \mathrm{C}$. Five micrograms of nuclear extracts were equilibrated for $15 \mathrm{~min}$ in binding buffer $(10 \mathrm{mM}$ Tris- $\mathrm{HCl}$, pH 8.0, $75 \mathrm{mM} \mathrm{KCl}, 2.5$ $\mathrm{mM} \mathrm{MgCl}, 0.1 \mathrm{mM}$ EDTA, $10 \%$ glycerol, $0.25 \mathrm{mM}$ DTT) and $1 \mu \mathrm{g}$ of poly dl/dC. ${ }^{32} \mathrm{P}$-labeled oligonucleotide probe $(20,000 \mathrm{cpm})$ was then added and the reaction was incubated on ice for an additional $20 \mathrm{~min}$. Bound and free DNA were then resolved by electrophoresis on a $6 \%$ native polyacrylamide gel in TBE buffer ( $89 \mathrm{mM}$ Tris- $\mathrm{HCl}, 89 \mathrm{mM}$ boric acid, and 2 mM EDTA).

\section{Cell adhesion assay}

Adherence of THP-1 cells to CRT-MG cells was assayed using a cell-cell adhesion assay as described elsewhere (Choi et al., 2004). Briefly, CRT-MG cells $\left(7.0 \times 10^{4}\right)$ were plated in 24-well glass chamber slide and exposed to HIV-1 Tat for $12 \mathrm{~h}$. The calcein-AM labeled THP-1 $\left(7.0 \times 10^{5}\right)$ was co-cultured with CRT-MG cells for $1 \mathrm{~h}$. Co- 
cultured cells were washed three times with PBS The fluorescence images were obtained at $485 \mathrm{~nm}$ excitation and $538 \mathrm{~nm}$ emission using a SPOT II digital camera-attached fluorescence microscope with Spot II data acquisition software (Diagnostic Instrument). For the adhesion quantification, the calcein-AM fluorescent intensity was measured at $485 \mathrm{~nm}$ excitation and $538 \mathrm{~nm}$ emission by a Fluoroskan ELISA plate reader (Labsystems Oy).

\section{Results}

\section{Delivery efficiency of SOD fusion proteins into astrocytes}

PEP-1 peptide, which has 21 amino acid residues, is a known carrier peptide that delivers exogenous protein into living cells (Morris et al., 2001). We have reported that the genetic in-frame PEP-1superoxide dismutase (PEP-1-SOD) was efficiently delivered in vitro and in vivo and exerted its protective effect against oxidative stress (Eum et al., 2004; Choi et al., 2006). To evaluate the cellular uptake of SOD fusion proteins into the human astrocytic cell line CRT-MG, SOD fusion proteins were added to cells at varying concentrations for 1 $h$, and the amounts of protein taken up were analyzed by Western blotting. As shown in Figure 1A, PEP-1-SOD efficiently entered the cells whereas the control SOD did not. Next, we analyzed the kinetics of incorporation of PEP-1-SOD (Figure $1 \mathrm{~B})$. As shown in Figure 1B, intracellular PEP-1SOD increased in a time-dependent manner. To investigate the stability of PEP-1-SOD in the cells, PEP-1-SOD was added to cultured media and incubated for various time intervals. And then, the levels of SOD fusion proteins in the cells were analyzed by Western blotting. The amount of intracellular PEP-1-SOD was constant for $3 \mathrm{~h}$, and then declined gradually (Figure 1C).

\section{The effect of the introduced PEP-1-SOD on ROS generation induced by HIV-1 Tat}

We previously reported that HIV-1 Tat can induce ROS generation in CRT-MG cells (Song et al., 2007). To examine the effect of SOD on ROS generation induced by HIV-1 Tat, CRT-MG cells were pretreated with SOD fusion proteins for $1 \mathrm{~h}$ and then exposed to HIV-1 Tat $(500 \mathrm{ng} / \mathrm{ml})$ for 15 min and the levels of intracellular ROS was evaluated by DCF-DA staining (Figure 2A) and NBT assay (Figure 2B). Pre-treatment with PEP-1SOD inhibited Tat-induced increase of intracellular ROS levels in CRT-MG cells whereas the control SOD had minimal effect (Figure 2A and $B$ ). These results indicate that PEP-1-SOD can efficiently remove ROS generation by HIV-1 Tat stimulation in CRT-MG cells.

\section{The effects of SOD on HIV-1 Tat-induced activation of NF- $\kappa B$}

$N F-\kappa B$ is one of redox-dependent transcription factors (Sen and Packer, 1996; Flohe et al., 1997), and we previously reported that ROS was involved in Tat-induced activation of NF- $\mathrm{B}$ in human astrocytes (Song et al., 2007). Next, we examined the effect of SOD on Tat-induced nuclear translocation and DNA binding ability of NF- $\kappa B$ in CRT-MG cells. CRT-MG cells were incubated in the presence of SOD fusion proteins for $1 \mathrm{~h}$, followed by exposure to HIV-1 Tat $(500 \mathrm{ng} / \mathrm{ml})$ for $1 \mathrm{~h}$. Nuclear accumulation of NF- $\mathrm{BB}$ p65 in HIV-1 Tat treated CRT-MG cells were strongly induced. PEP-1-SOD prevented Tat-induced translocation of p65, as analyzed by fluorescence microscopy and Western blot technique (Figure $3 A$ and $B$ ). In addition, pretreatment with PEP-1-SOD suppressed Tat-induced DNA binding activity of NF- $\mathrm{B}$ (Figure $3 \mathrm{C}$ ).

A

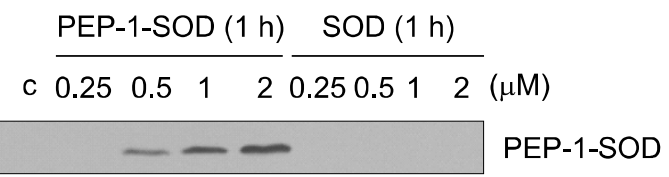

B

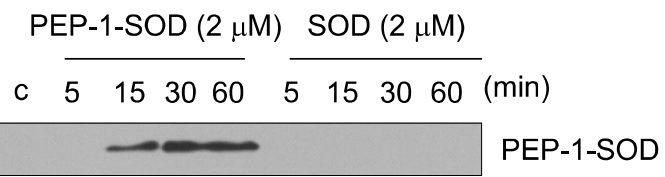

C

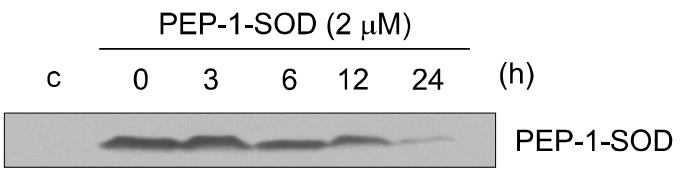

Figure 1. Cellular uptake of SOD fusion proteins. (A) Dose-dependent cellular uptake of SOD fusion proteins. CRT-MG cells were incubated with various concentrations of PEP-1-SOD or SOD for $1 \mathrm{~h}$. Cellular lysates were prepared for Western blot analysis for determining the cellular uptake of SOD fusion proteins. (B) Time-dependent uptake of PEP-1SOD into cells. CRT-MG cells were incubated with $2 \mu \mathrm{M}$ of the PEP-1-SOD for the indicated time. (C) To examine stability of the intracellular PEP-1-SOD, the cells were incubated with $2 \mu \mathrm{M}$ of the PEP-1-SOD for $1 \mathrm{~h}$ and washed twice with serum-free media. The cells were incubated with new culture media and harvested at the indicated time. Cell lysates were analyzed by Western blotting. C, untreated control cell lysates. 
A
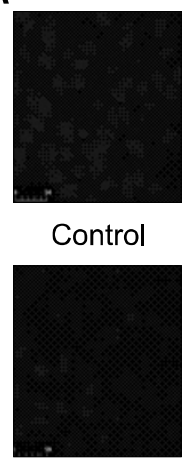

SOD

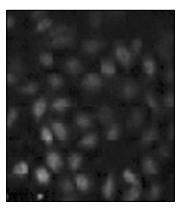

PEP-1-SOD $0.5 \mu \mathrm{M} / \mathrm{Tat}$

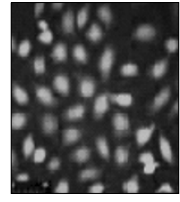

$\mathrm{H}_{2} \mathrm{O}_{2}$

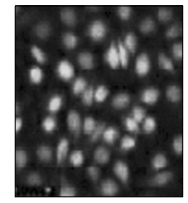

SOD/Tat

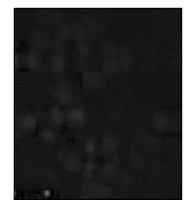

PEP-1-SOD

$1 \mu \mathrm{M} / \mathrm{Tat}$

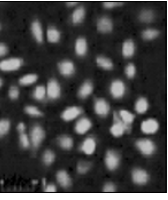

Tat

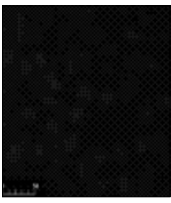

PEP-1-SOD

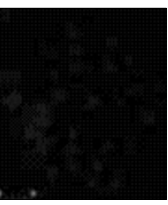

PEP-1-SOD

$2 \mu \mathrm{M} / \mathrm{Tat}$
B

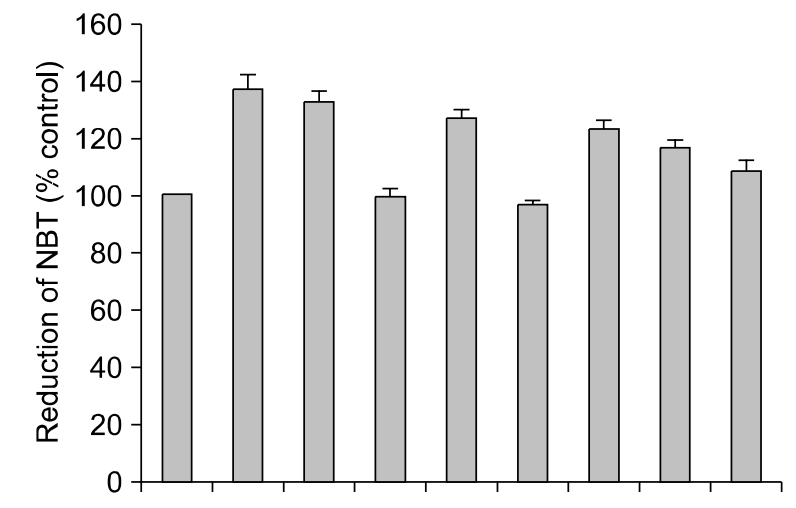

\begin{tabular}{|c|c|c|c|c|c|c|c|c|c|}
\hline Tat & - & - & + & - & + & - & + & + & + \\
\hline SOD & - & - & - & + & + & - & - & - & - \\
\hline PEP-1-SOD & - & - & - & - & - & 2 & 0.5 & 1 & 2 \\
\hline $\mathrm{H}_{2} \mathrm{O}_{2}$ & - & + & - & - & - & - & - & - & - \\
\hline
\end{tabular}

Figure 2. Effects of SOD fusion proteins on HIV-1 Tat-induced ROS generation in the CRT-MG cells. CRT-MG cells were treated with $0.5,1$ and $2 \mu \mathrm{M}$ PEP-1-SOD or $2 \mu \mathrm{M}$ SOD fusion proteins for $1 \mathrm{~h}$, and then exposed to HIV-1 Tat (500 ng/ml) for $15 \mathrm{~min}$. (A) Intracellular ROS levels were measured after staining with a fluorescent dye, DCF-DA. Visualization of the ROS of the treated cells was measured by confocal microscopy (original magnification, $\times$ 400). (B) The ROS level was measured by NBT reduction. The data are the mean \pm SEM of three separate experiments.

\section{Inhibition of HIV-1 Tat-induced MAPK activation by PEP-1-SOD in CRT-MG}

The MAPK signaling cascades have been shown to be involved in activation of NF- $\mathrm{B}$ upon HIV-1 Tat stimulation (Badou et al., 2000; Bruce-Keller et al., 2001; Liu et al., 2002, 2005). Several lines of evidence have indicated that ROS has a regulatory role in the activity of MAPKs such as p38, JNK and ERK protein kinase (Kyaw et al., 2004). To examine the effect of SOD on HIV-1 Tat induced MAPK activation, CRT-MG cells were incubated in the absence or presence of PEP-1-SOD or SOD fusion protein for $1 \mathrm{~h}$, followed by exposure to HIV1 Tat $(500 \mathrm{ng} / \mathrm{ml})$ for $1 \mathrm{~h}$, and then MAPK activation was analyzed by Western blot analysis (Figure 4). PEP-1-SOD suppressed HIV-1 Tat-induced MAPK activation in a dose-dependent manner in CRT-MG cells.

\section{Effects of SOD on HIV-1 Tat-induced expression of ICAM-1 and VCAM-1}

ICAM-1 and VCAM-1 expression is regulated by different transcription factors including $N F-\kappa B$ in astrocytes (Lee et al., 1998). We previously reported that ROS was involved in Tat-induced increase of ICAM-1 and VCAM-1 expression by human astrocytes (Song et al., 2007). We further used these SOD fusion proteins to analyze the role of ROS on Tat-induced up-regulation of ICAM-1 and VCAM-1 expression in CRT-MG cells. Cells were incubated in the absence or presence of SOD fusion proteins for $1 \mathrm{~h}$, treated with Tat (500 $\mathrm{ng} / \mathrm{ml}$ ), and then ICAM-1 and VCAM-1 expression were analyzed by RT-PCR and Western blot analysis. Pre-treatment with PEP-1-SOD inhibited markedly ICAM-1 and VCAM-1 mRNA (Figure 5A) and protein (Figure 5B) expression.

\section{Effects of SOD on HIV-1 Tat-induced monocyte adhesion to astrocytes}

To further confirm the relevance between ROS production and monocyte adhesion, we examined the effect of SOD on monocyte adhesion to CRT-MG cells. CRT-MG cells were incubated in the absence or presence of SOD fusion proteins for $1 \mathrm{~h}$, treated with Tat $(500 \mathrm{ng} / \mathrm{ml})$, and then analyzed for monocyte adhesion to CRT-MG cells. As shown in Figure 6, adhesion between THP-1 and CRT-MG cells induced by HIV-1 Tat decreased significantly when the CRT-MG cells were pre-treated with 

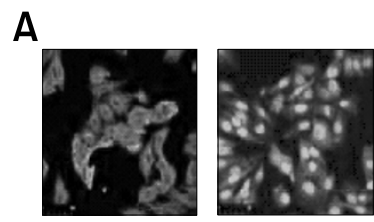

Control

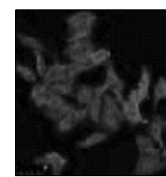

TNF- $\alpha$

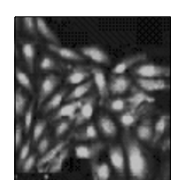

SOD

$2 \mu \mathrm{M}$

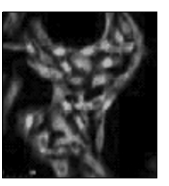

$2 \mu \mathrm{M} /$ Tat

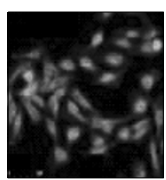

$0.5 \mu \mathrm{M} / \mathrm{Ta}$

PEP-1-SOD

$1 \mu \mathrm{M} / \mathrm{Tat}$

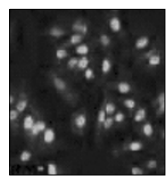

Tat

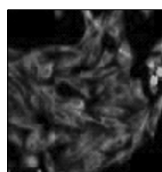

PEP-1-SOD

$2 \mu \mathrm{M}$

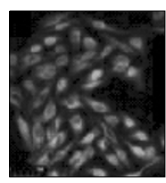

PEP-1-SOD

$2 \mu \mathrm{M} / \mathrm{Tat}$

B

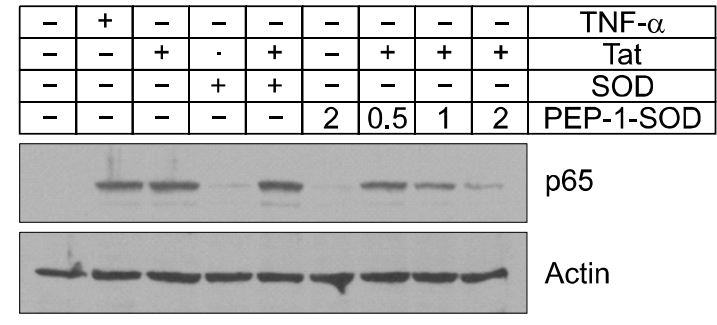

C
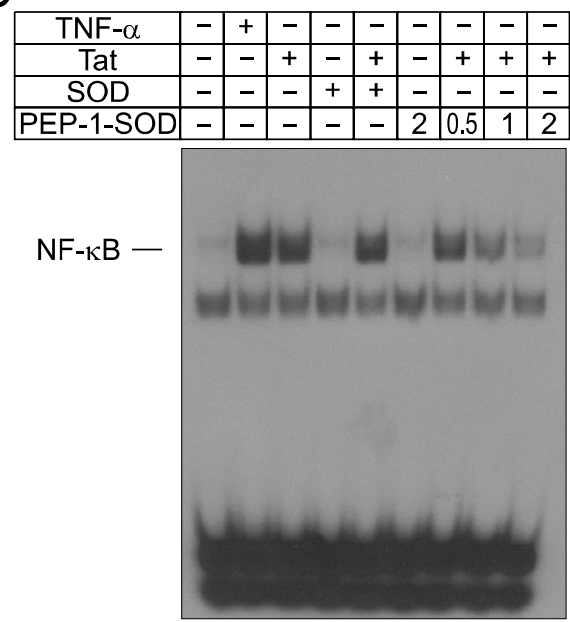

Figure 3. Effect of SOD fusion proteins on the NF-KB nuclear localization and DNA-binding activity in CRT-MG cells exposed to HIV-1 Tat protein. CRT-MG cells were treated with HIV-1 Tat protein $(500 \mathrm{ng} / \mathrm{ml})$ for $1 \mathrm{~h}$ with or without pretreatment with the PEP-1-SOD or SOD fusion proteins. NF- $\mathrm{KB}$ nuclear localization was visualized with a confocal microscopy by indirect immunofluorescence using anti-NF- $\mathrm{kB}$ p65 antibody (A). Nuclear extracts were prepared from the CRT-MG cells treated with HIV-1 Tat and the levels of p65 were determined by Western blot analysis (B). DNA-binding activity of NF-KB in the nuclear extracts of the CRT-MG cells was measured by EMSA (C).

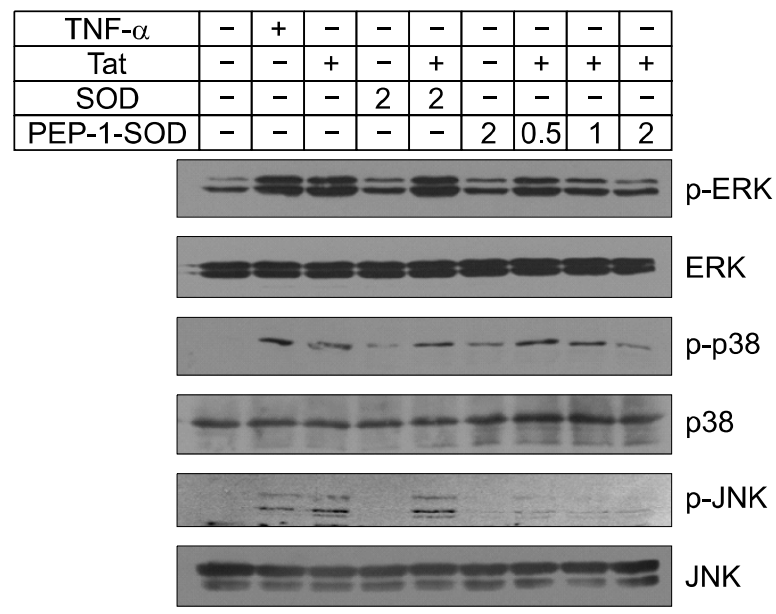

Figure 4. Effect of SOD fusion proteins on the MAPK activation in CRT-MG cells exposed to HIV-1 Tat protein. CRT-MG cells were treated with HIV-1 Tat protein $(500 \mathrm{ng} / \mathrm{ml})$ for $1 \mathrm{~h}$ with or without pretreatment with PEP-1-SOD or SOD fusion protein for $1 \mathrm{~h}$. Cell extracts were prepared and analyzed for MAPK protein activation.

A

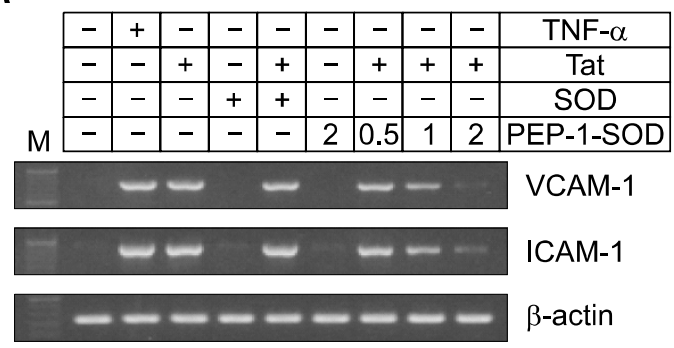

B

\begin{tabular}{|c|c|c|c|c|c|c|c|c|c|}
\hline- & + & - & - & - & - & - & - & - & TNF- $\alpha$ \\
\hline- & - & + & . & + & - & + & + & + & Tat \\
\hline- & - & - & + & + & - & - & - & - & SOD \\
\hline - & - & - & - & - & 2 & 0.5 & 1 & 2 & PEP-1-SOD \\
\hline \multicolumn{4}{|c|}{ ens } & $r$ & & \multicolumn{3}{|c|}{$-2+1$} & VCAM-1 \\
\hline \multicolumn{9}{|c|}{ 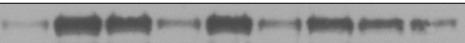 } & ICAM-1 \\
\hline \multicolumn{9}{|c|}{$-5-6-2$} & Actin \\
\hline
\end{tabular}

Figure 5. Effects of SOD fusion proteins on HIV-1 Tat-induced VCAM-1 and ICAM-1 expression in CRT-MG cells. (A) CRT-MG cells were treated with $0.5,1$ and $2 \mu \mathrm{M}$ PEP-1-SOD or $2 \mu \mathrm{M}$ SOD fusion proteins for $1 \mathrm{~h}$, and then exposed to HIV-1 Tat protein $(500 \mathrm{ng} / \mathrm{ml})$ for $8 \mathrm{~h}$. Total RNA was extracted. VCAM-1, ICAM- 1 and $\beta$-actin mRNA were analyzed by RT-PCR using specific primers. (B) CRT-MG cells were treated with HIV-1 Tat protein $(500 \mathrm{ng} / \mathrm{ml})$ for $12 \mathrm{~h}$ with or without pretreatment with PEP-1-SOD or SOD fusion protein for $1 \mathrm{~h}$. Cell extracts were prepared and analyzed by Western blotting for VCAM-1 and ICAM-1 protein expression. TNF- $\alpha(10 \mathrm{ng} / \mathrm{ml})$ was used as a positive control. 

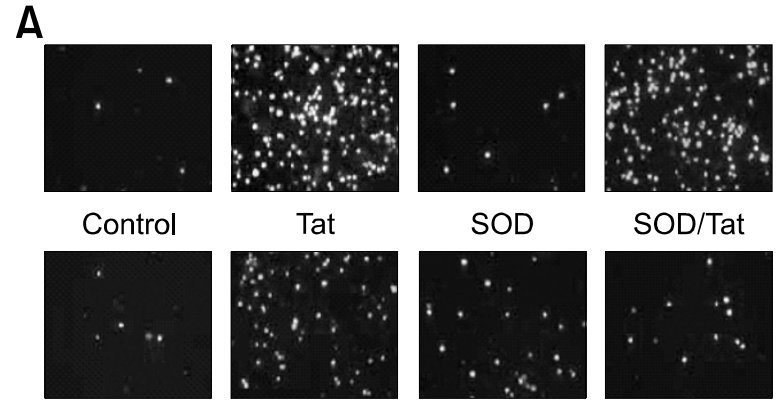

Tat

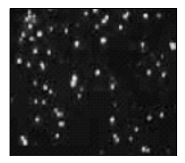

SOD

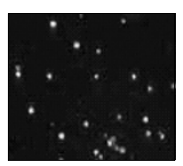

SOD/Tat

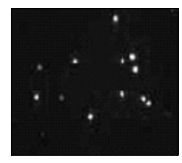

PEP-1-SOD

PEP-1-SOD
$0.5 \mu \mathrm{M} / \mathrm{Tat}$

PEP-1-SOD

$2 \mu \mathrm{M} / \mathrm{Tat}$

\section{B}

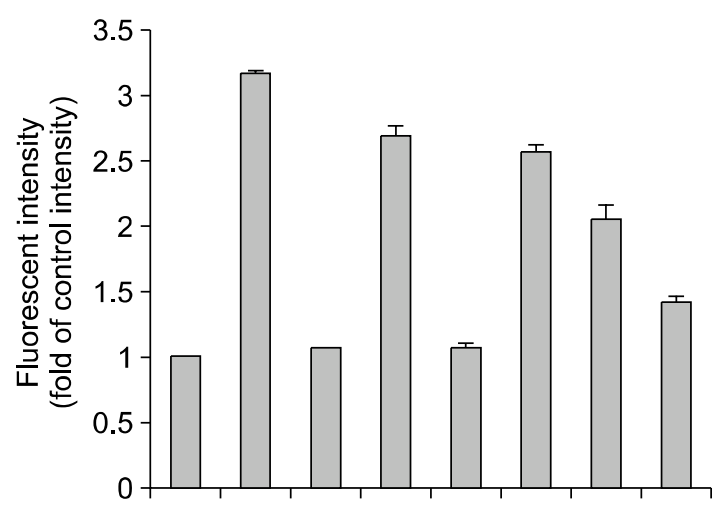

\begin{tabular}{|c|c|c|c|c|c|c|c|c|}
\hline Tat & - & + & - & + & - & + & + & + \\
\hline SOD & - & - & + & + & - & - & - & - \\
\hline PEP-1-SOD & - & - & - & - & 2 & 0.5 & 1 & 2 \\
\hline
\end{tabular}

Figure 6. Inhibition of HIV-1 Tat-induced monocyte adhesion to CRT-MG by PEP-1-SOD fusion protein. CRT-MG cells were treated with $0.5,1$ and $2 \mu \mathrm{M}$ PEP-1-SOD or $2 \mu \mathrm{M}$ SOD fusion proteins for $1 \mathrm{~h}$ and followed by exposure to HIV-1 Tat protein $(500 \mathrm{ng} / \mathrm{ml})$ for $12 \mathrm{~h}$. CRT-MG cells were co-cultured with calcein-AM-labeled THP-1 monocytes. (A) Microphotographs were obtained using fluorescence microscopy (original magnification, $\times 40$ ). (B) The calcein-AM fluorescent intensity was measured by an ELISA plate reader. Values are means $\pm \mathrm{SEM}, n=3$.

PEP-1-SOD (Figure 6A and B). These results indicate that ROS is required for Tat-induced expression of ICAM-1 and VCAM-1 and subsequent adheson of monocyte to astrocytes.

\section{Discussion}

HIV-1 Tat can induce upregulation of adhesion molecules and cytokine/chemokine dysregulation which may induce a series of interactions between monocytes, endothelial cells, and astrocytes, resulting in enhanced infiltration of monocytes into the CNS (Rappaport et al., 1999; Langford and Masliah, 2001). Upon HIV-1 Tat stimulation, astrocytes can express the increased level of adhesion molecules such as ICAM-1 and VCAM-1, which lead to monocyte entry into the CNS (Rappaport et al., 1999; Pu et al., 2003). Previous studies demonstrated that intracerebral administration of HIV-1 Tat in mouse induced expression of adhesion molecules, such as ICAM-1 and VCAM-1, leading to monocyte infiltration which induced profound proinflammatory effects in the brain, suggesting that HIV-1 Tat alone can markedly contribute to the development of ADC in HIV-1infected patients (Pu et al., 2003). We previously reported that HIV-1 Tat can modulate monocyte adhesiveness by increasing expression of adhesion molecules such as ICAM-1 and VCAM- 1 via ROS- and NF- $\kappa$ B-dependent mechanisms in astrocytes (Song et al., 2007). Further understanding of the role of ROS generation in Tat mediated infiltration of monocyte into the CNS might help to develop a therapeutic tool for ADC. In this study, we examined the effect of superoxide dismutase on HIV-1 Tat-induced expression of adhesion molecules such as ICAM-1 and VCAM- 1 , and subsequent monocyte adhesion by astrocyte. We show that SOD suppressed HIV-1 Tat-induced ROS generation, activation of NF- $\mathrm{KB}$ and subsequent expression of adhesion molecules and monocyte adhesion in human astrocytes.

Since ROS plays a major role in a variety of neurodegenerative and neuroinflammatory diseases such as Alzheimer's disease (Keller et al., 1999; Wang and Joseph, 1999), there have been considerable efforts in the use of anti-oxidant enzymes in protection against ROS-mediated diseases (Greenwald, 1990). Recombinant enzymes such as SOD and catalase have been used to protect against oxidative stresses. We generated a cell permeable SOD, PEP-1-SOD, by use of a peptide that is capable of delivering protein into cells. Cell-permeable SOD has been shown to be beneficial in several oxidative stress models such as ischemia, Parkinson disease, and diabetes (Eum et al., 2004; Choi et al., 2006).

Previous studies have shown by using various anti-oxidants that HIV-1 Tat induced ROS mediates various cellular functions such as NF- $\kappa B$ activation, MAPK activation, and expression of proinflammatory molecules including adhesion molecules. However, broad effects of anti-oxidants on the cellular functions hampers to study the exact role of ROS in HIV-1 Tat induced cellular dysregulation such as NF- $\kappa B$ activation. We have previously shown that expression of ICAM-1 and VCAM-1 was up-regulated at the transcriptional level via ROS- and NF- $\kappa B$-dependent pathways upon HIV-1 Tat stimulation (Song et al., 2007).

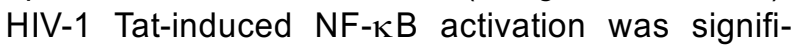


cantly inhibited in cells treated with HIV-1 Tat in the presence of PEP-1-SOD (Figure 3), indicating the functional consequence of ROS generation by Tat. Treatment of CRT-MG cells with PEP-1-SOD before exposure to HIV-1 Tat significantly inhibited activation of MAPKs such as ERK, JNK and p38. Furthermore, application of PEP-1-SOD significantly suppressed HIV-1 Tat induced upregulation of ICAM-1/VCAM-1 expression and subsequent enhanced monocyte adhesion to astrocyte. These results indicate that ROS is involved in the signaling pathway leading to activation of $\mathrm{NF}-\mathrm{KB}$ and to

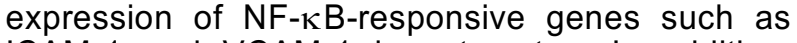
ICAM-1 and VCAM-1 in astrocytes. In addition, theses results demonstrate that the PEP-1-SOD has anti-oxidant and anti-inflammatory activities.

In consistent with our results, several reports have indicated that SOD has a regulatory role in proinflammatory responses. Stable overexpression of SOD attenuated significantly LPS-induced acti-

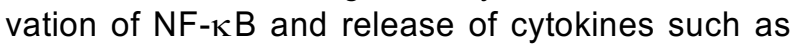
TNF- $\alpha$ and IL- 6 in microglial cells (Dimayuga et al., 2007). In addition, SOD overexpression mediated by adenoviral vector effectively inhibited activation of $N F-\kappa B$ and expression of adhesion molecules such as ICAM-1/VCAM-1 upon TNF- $\alpha$ stimulation in human endothelial cells (Lin et al., 2005). Taken together, these studies suggest that SOD has anti-inflammatory activities and may play important roles in modulating ROS-dependent signaling pathways and inflammation response.

Although the exact sources of ROS generation induced by HIV-1 Tat in astrocyte have not been elucidated, inhibition of HIV-1 Tat-induced generation of ROS by DPI, suggests the involvement of a NADPH oxidase (Song et al., 2007). We are studying the possible role of NOX family in Tatinduced NF- $\kappa \mathrm{B}$ activation to define the exact molecular source of ROS generation upon HIV-1 Tat stimulation.

In conclusion, the inhibitory activity of PEP-1SOD in Tat-mediated adhesion molecule expression and subsequent increased adhesion of monocyte to astrocyte implicates that SOD has a regulatory function in the HIV-1 Tat-induced signaling pathways leading to NF- $\kappa \mathrm{B}$ activation. PEP-1SOD has been shown to be beneficial in several oxidative stress models such as ischemia and Parkinson's disease (Eum et al., 2004; Choi et al., 2006). Cell-permeable SOD can be used as a therapeutic agent against Tat-induced ROS-associated neurotoxicity.

\section{Acknowledgments}

This work was supported in part by a Next Generation
Growth Engine Program Grant from the Korean Science and Engineering Foundation, and in part by a Regional Innovation Center Grant from the Korean Ministry of Commerce, Industry and Energy.

\section{References}

Badou A, Bennasser Y, Moreau M, Leclerc C, Benkirane M, Bahraoui E. Tat protein of human immunodeficiency virus type 1 induces interleukin-10 in human peripheral blood monocytes: implication of protein kinase C-dependent pathway. J Virol 2000;74:10551-62

Brenneisen P, Sies H, Scharffetter-Kochanek K. Ultraviolet$B$ irradiation and matrix metalloproteinases: from induction via signaling to initial events. Ann N Y Acad Sci 2002;973: $31-43$

Bruce-Keller AJ, Barger SW, Moss NI, Pham JT, Keller JN, Nath A. Pro-inflammatory and pro-oxidant properties of the HIV protein Tat in a microglial cell line: attenuation by 17 beta-estradiol. J Neurochem 2001;78:1315-24

Choi C, Kutsch O, Park J, Zhou T, Seol DW, Benveniste EN. Tumor necrosis factor-related apoptosis-inducing ligand induces caspase-dependent interleukin- 8 expression and apoptosis in human astroglioma cells. Mol Cell Biol 2002; 22:724-36

Choi HS, An JJ, Kim SY, Lee SH, Kim DW, Yoo KY, Won MH, Kang TC, Kwon HJ, Kang JH, Cho SW, Kwon OS, Park J, Eum WS, Choi SY. PEP-1-SOD fusion protein efficiently protects against paraquat-induced dopaminergic neuron damage in a Parkinson disease mouse model. Free Radic Biol Med 2006;41:1058-68

Choi JS, Choi YJ, Park SH, Kang JS, Kang YH. Flavones mitigate tumor necrosis factor-alpha-induced adhesion molecule upregulation in cultured human endothelial cells: role of nuclear factor-kappa B. J Nutr 2004;134:1013-9

Dhawan S, Singh S, Aggarwal BB. Induction of endothelial cell surface adhesion molecules by tumor necrosis factor is blocked by protein tyrosine phosphatase inhibitors: role of the nuclear transcription factor NF-kappa B. Eur J Immunol 1997;27:2172-9

Dimayuga FO, Wang C, Clark JM, Dimayuga ER, Dimayuga VM, Bruce-Keller AJ. SOD1 overexpression alters ROS production and reduces neurotoxic inflammatory signaling in microglial cells. J Neuroimmunol 2007;182:89-99

D'Aversa TG, Yu KO, Berman JW. Expression of chemokines by human fetal microglia after treatment with the human immunodeficiency virus type 1 protein Tat. J Neurovirol 2004; 10:86-97

Eum WS, Kim DW, Hwang IK, Yoo KY, Kang TC, Jang SH, Choi HS, Choi SH, Kim YH, Kim SY, Kwon HY, Kang JH, Kwon OS, Cho SW, Lee KS, Park J, Won MH, Choi SY. In vivo protein transduction: biologically active intact pep-1-superoxide dismutase fusion protein efficiently protects against ischemic insult. Free Radic Biol Med 2004;37:1656-69

Greenwald RA. Superoxide dismutase and catalase as 
therapeutic agents for human diseases. A critical review. Free Radic Biol Med 1990;8:201-9

Flohe L, Brigelius-Flohe R, Saliou C, Traber MG, Packer L. Redox regulation of NF-kappa B activation. Free Radic Biol Med 1997;22:1115-26

Keller JN, Hanni KB, Gabbita SP, Friebe V, Mattson MP, Kindy MS. Oxidized lipoproteins increase reactive oxygen species formation in microglia and astrocyte cell lines. Brain Res 1999;29;830:10-5

Kim DS, Han JH, Kwon HJ. NF-kappaB and c-Jun-dependent regulation of macrophage inflammatory protein-2 gene expression in response to lipopolysaccharide in RAW 264.7 cells. Mol Immunol 2003;40:633-43

Kyaw M, Yoshizumi M, Tsuchiya K, Izawa Y, Kanematsu Y, Tamaki T. Atheroprotective effects of antioxidants through inhibition of mitogen-activated protein kinases. Acta Pharmacol Sin 2004;25:977-85

Langford D, Masliah E. Crosstalk between components of the blood brain barrier and cells of the CNS in microglial activation in AIDS. Brain Pathol 2001;11:306-12

Lee SJ, Hou J, Benveniste EN. Transcriptional regulation of intercellular adhesion molecule-1 in astrocytes involves NF-kappaB and C/EBP isoforms. J Neuroimmunol 1998;92: 196-207

Lin SJ, Shyue SK, Hung YY, Chen YH, Ku HH, Chen JW, Tam $\mathrm{KB}$, Chen YL. Superoxide dismutase inhibits the expression of vascular cell adhesion molecule-1 and intracellular cell adhesion molecule-1 induced by tumor necrosis factoralpha in human endothelial cells through the JNK/p38 pathways. Arterioscler Thromb Vasc Biol 2005;25:334-40

Liu K, Chi DS, Li C, Hall HK, Milhorn DM, Krishnaswamy G. HIV-1 Tat protein-induced VCAM-1 expression in human pulmonary artery endothelial cells and its signaling. Am J Physiol Lung Cell Mol Physiol 2005;289:L252-60

Liu X, Jana M, Dasgupta S, Koka S, He J, Wood C, Pahan K. Human immunodeficiency virus type 1 (HIV-1) tat induces nitric-oxide synthase in human astroglia. J Biol Chem 2002; 277:39312-19

Morris MC, Depollier J, Mery J, Heitz F, Divita G. A peptide carrier for the delivery of biologically active proteins into mammalian cells. Nat Biotechnol 2001;19:1173-6

Nicolini A, Ajmone-Cat MA, Bernardo A, Levi G, Minghetti L. Human immunodeficiency virus type-1 Tat protein induces nuclear factor (NF)-kappaB activation and oxidative stress in microglial cultures by independent mechanisms. J Neurochem 2001;79:713-6

Ozdener H. Molecular mechanisms of HIV-1 associated neurodegeneration. J Biosci 2005;30:391-405

Park J, Kwon D, Choi C, Oh JW, Benveniste EN. Chloroquine induces activation of nuclear factor-kappaB and subsequent expression of pro-inflammatory cytokines by human astroglial cells. J Neurochem 2003;84:1266-74

Park J, Choi K, Jeong E, Kwon D, Benveniste EN, Choi C. Reactive oxygen species mediate chloroquine-induced expression of chemokines by human astroglial cells. Glia 2004; $47: 9-20$

Pu H, Tian J, Flora G, Lee YW, Nath A, Hennig B, Toborek M. HIV-1 Tat protein upregulates inflammatory mediators and induces monocyte invasion into the brain. Mol Cell Neurosci 2003;24:224-37

Rappaport J, Joseph J, Croul S, Alexander G, Del Valle L, Amini S, Khalili K. Molecular pathway involved in HIV-1induced CNS pathology: role of viral regulatory protein, Tat. J Leukoc Biol 1999;65:458-65

Rook GA, Steele J, Umar S, Dockrell HM. A simple method for the solubilisation of reduced NBT, and its use as a colorimetric assay for activation of human macrophages by gamma-interferon. J Immunol Methods 1985;82:161-7

Rumbaugh JA, Nath A. Developments in HIV neuropathogenesis. Curr Pharm Des 2006;12:1023-44

Schulze-Osthoff K, Bauer MK, Vogt M, Wesselborg S. Oxidative stress and signal transduction. Int J Vitam Nutr Res 1997;67:336-42

Sen CK, Packer L. Antioxidant and redox regulation of gene transcription. FASEB J 1996;10:709-20

Song HY, Ryu J, Ju SM, Park LJ, Lee JA, Choi SY, Park J. Extracellular HIV-1 Tat enhances monocyte adhesion by up-regulation of ICAM-1 and VCAM-1 gene expression via ROS-dependent NF-kappaB activation in astrocytes. Exp Mol Med 2007;39:27-37

Tarpey MM, Fridovich I. Methods of detection of vascular reactive species: nitric oxide, superoxide, hydrogen peroxide, and peroxynitrite. Circ Res 2001;89:224-36

Wang $\mathrm{H}$, Joseph JA. Quantifying cellular oxidative stress by dichlorofluorescein assay using microplate reader. Free Radic Biol Med 1999;27:612-6

Weiss JM, Nath A, Major EO, Berman JW. HIV-1 Tat induces monocyte chemoattractant protein-1-mediated monocyte transmigration across a model of the human blood-brain barrier and up-regulates CCR5 expression on human monocytes. J Immunol 1999;163:2953-9

Woodman SE, Benveniste EN, Nath A, Berman JW. Human immunodeficiency virus type 1 TAT protein induces adhesion molecule expression in astrocytes. J Neurovirol 1999;5:67884

Zhang SY, Park KW, Oh S, Cho HJ, Cho HJ, Park JS, Cho YS, Koo BK, Chae IH, Choi DJ, Kim HS, Lee MM. NF-kappaB decoy potentiates the effects of radiation on vascular smooth muscle cells by enhancing apoptosis. Exp Mol Med 2005;37: 18-26 